E não há nenhuma nota consistente e substancial a respeito da iniciação ao culto dos Zar. Nenhuma informação sôbre as atividades mágico-religiosas dos possuídos pelos Zar nos períodos não propícios às grandes concentrações populares.

Há, ademais, falhas capitais.

Do ponto de vista metodológico, não teria sido mais razoável, mais certo e mais prudente ter o Autor procurado verificar nos grupos sócioculturais vizinhos e, em seguida, nos grupos africanos mais afastados (Eritréia e Sudão), as instituições congêneres à dos Zar para fins de filiação e comparação? Não resta dúvida que o xamanismo pode ser empregado como um conceito classificatório, para abordagem de assunto que nêle se enquadre; mas, para sempre, não. Porventura, o estudioso não viria a correr o perigo de reduzir a uma fórmula consagrada tôda uma série nova de situações que sob certos aspectos nada têm a ver com ela?

$\mathrm{E}$, finalmente, há a falha que, para nós, faz dêste livro um lamentável equívoco.

A indagação, que se estende como têma único pelos cinco capítulos, possessão autêntica ou possessão simulada, nunca teria sido feita por um antropólogo. Poder-se-ia tomar em dois sentidos o que o Autor 'chama de possessão autêntica: um psicológico e outro antropológico. Do ponto de vista psicológico, a questão se resumiria na verificação do grau de inconsciência do indivíduo durante a tomada ou transe, e possessão autêntica seria o estado em que o indivíduo, tendo recorrido a meios mecânicos, medicinais ou seja lá o que fôr, tem sua consciência obnubilada e passa a agir ao impulso de outros elementos da vida psíquica, ou, pedindo vênia aos psicólogos, da vida sócio-cultural profundamente calcados na esfera do inconsciente. Nesse sentido sim é que se justificaria a preocupação do Autor, caso o seu trabalho não fôsse de etnologia. Do ponto de vista antropológico, a coisa é considerada diferentemente. Seria fora de propósito estar a repetir aqui tudo o que já se propôs a respeito de cultura e vida social, mas, para nós, possessão autêntica é isto: um estado especial de comportamento em que o indivíduo, consciente ou inconscientemente, emocionalmente dominado por uma crença ou apenas executando um ato de acôrdo com rituais pré-estabelecidos, funciona como meio veiculador de elementos mágicos e religiosos de uma cultura que, por sua vez, ainda esteja a corresponder às necessidades, solicitações e experiências de uma dada sociedade. Dessa maneira a possessão é sempre autêntica, e mesmo perante os casos em que há charlatanismo, impostura ou paródia, ela ainda é autêntica, porque pode estar a pontear os processos de mudança social, de secularização. Enfim, desde que a possessão corresponda às solicitações da vida sócio-cultural, ela é sempre autêntica ou verdadeira.

Tivesse o Autor elaborado um livro com menos veleidades, teríamos ganho mais uma monografia muito interessante sôbre crenças e práticas mágico-religiosas.

\title{
O. E. Xidieh
}

HANS HIMMELHEBER: Der gute Ton bei den Negern. 104 págs. Verlag Richters \& Co., Heidelberg, 1957. (Preço: DM 6,80).

Hans Himmelheber empreendeu ao todo seis expedições etnológicas à África Negra. Trabalhou na Libéria, na Costa do Marfim, no Sudão Francês, no Camerum, no Gabon e no Congo Belga. São, assim, bastante ex- 
tensos os seus conhecimentos de culturas africanas. Estudos mais intensivos realizou-os desde 1950 entre os Dan, população de umas duzentas mil almas estabelecida nas florestas ocidentais da Costa do Marfim, e orientais da Libéria. Em três expedições percorreu o território dêsses agricultores aborígenes, sôbre os quais publicou um estudo monográfico em colaboração com Ulrike Himmelheber, sua espôsa.

Embora o presente volume tenha por assunto o "bom tom", isto é, as formas de etiqueta na África Negra em geral, a maior parte dos exemplos nêle contidos se refere à cultura dos Dan. Uma bibliografia de mais de setenta títulos, arrolada no fim do livro, forneceu ao Autor abundantes dados para observações comparativas com outras regiões, da África e fora dela. Conquanto escrito por um etnólogo, Der gute Ton bei den Negern é trabalho de caráter essencialmente popular. Para coordenar o material, aliás bastante variado e heterogêneo, o Autor o repartiu em cinco capítulos. No primeiro traça, a título de introdução, um quadro sumário de costumes dos negros africanos; no segundo, dedicado às expressões de cortesia, passa em revista principalmente as formas de saudação, os gestos de $\mathrm{vaz}$ e os de hostilidade; no terceiro discute conceitos e costumes referentes à hospitalidade; o quarto, talvez o mais interessante, trata da idéia de dignidade e das atitudes e formas de comportamento a ela ligadas; no quinto, por fim, se esboçam traços de caráter peculiares a determinadas tribos em suas relações com o código de regras morais e as concepções de justiça. Segue-se um apêndice, no qual se narram quatro mitos de fundo ético registrados entre os Dan.

Apesar dessa divisão em capítulos, não se observa nenhuma seqüência rígida na apresentação dos fatos, que se vão sucedendo de forma um tanto arbitrária e em geral como simples notas de viagem, por assim dizer ao correr da pena. Resulta, assim, um mosaico de episódios anedóticos, de caráter mais ou menos pitoresco. A compreensão do texto não exige quaisquer conhecimentos etnológicos. Himmelheber se abstém, aliás, conscientemente de tôda discussão de problemas científicos, mas, por outro lado, imprime ao seu livrinho um cunho educativo. Através de exemplos significativos, vai mostrando quão longe se encontram da verdade os que ainda acreditam que os chamados povos primitivos, em virtude de traços peculiares a sua constituição psíquica, não comungam da natureza humana em sua plenitude. A constante preocupação com o status social, o senso da dignidade humana, o respeito à personalidade do próximo e especialmente o tato nas relações sociais aparecem por vêzes muito mais arraigados no espírito do primitivo do que no do ocidental civilizado. E ao mostrar quanto o negro africano difere do branco europeu, o Autor mostra também, implìcitamente, que a diversidade, bem compreendida, é muito mais aparente do que real. Para o etnólogo, é claro, não há em tudo isso nenhuma descoberta nova, mas o leitor leigo encontra no conjunto dos fatos e exemplos um salutar estímulo para encarar com suspeita os seus juízos etnocêntricos. E como êste é, por sua vez, o primeiro passo decisivo a ser dado pelos que procurem iniciar-se com algum proveito no estudo da Etnologia, é evidente que a leitura do livrinho de Himmelheber será útil também aos principiantes nessa disciplina científica.

O simpático volume é ilustrado com artísticos desenhos de Kurt Steinel.

Egon Schaden 